\title{
The Spread of Confucianism in Hayao Miyazaki's Animations
}

\author{
Daoshan Ma*, Linlin Cheng \\ School of Foreign Languages, Tianjin Polytechnic University, Tianjin, China \\ Email: *madaos@tom.com
}

How to cite this paper: Ma, D.S. and Cheng, L.L. (2016) The Spread of Confucianism in Hayao Miyazaki's Animations. Open Access Library Journal, 3: e3129. http://dx.doi.org/10.4236/oalib.1103129

Received: October 11, 2016

Accepted: October 25, 2016

Published: October 28, 2016

Copyright $\odot 2016$ by authors and Open Access Library Inc.

This work is licensed under the Creative Commons Attribution International

License (CC BY 4.0).

http://creativecommons.org/licenses/by/4.0/

(c) (†) Open Access

\begin{abstract}
This thesis is an exploration of the themes and symbols of Confucian culture in the early animated feature films of Hayao Miyazaki. It deals with the background and knowledge of the selected topic, the profound meaning of Hayao Miyazaki's animation and the spread of Confucian culture in his animations which convey distinctive ethos and the advanced experience of success. Hayao Miyazaki's animations have inherited traditional oriental cultural morality, and embodied the pursuit of universal values, such as people's care for the vulnerable, their cherishing of the family, their praise of the friendship, their encouragement for the spirit of struggle and hard work, and their fight against misfortunes. Hayao Miyazaki's animations play an important role in spreading Confucianism to the world.
\end{abstract}

\section{Subject Areas}

Art, Philosophy

\section{Keywords}

Hayao Miyazaki, Animation, Confucian Culture

\section{Introduction}

As a hero, Miyazaki brings creativity and inspiration to the world. He makes people smile and laugh, and cry and dream with his wonderful pictures and characters that are drawn in amazing details. His stories are so magnificent that they make you wonder how he could make them up. He can be funny and artistic at the same time.

In all of Hayao Miyazaki's films, there are repetitive themes that he presents to the crowd. Even though these themes always appear in his films, it's what the story and artwork that makes these films unique. In his films, he uses the same artistic skill to create his characters. The worlds that he creates are based on different cultures and 
places that he has visited. His films are for any person to enjoy because his films seem more tied to the children. In all of Miyazaki's films, there is a big piece of himself in each one [1]. Some of the scenes were based on his life experiences. A lot of the characters are based on friends and people he knows. The locations and how people dress are what he has seen. He studies how people work, and because he knows how people work, it makes his animations much real.

Hayao Miyazaki's animations have inherited Confucian culture and traditional oriental cultural morality, and embodied the pursuit of universal values, such as the care for the vulnerable, the cherishment of the family, the praise of human friendship, the encouragement for the spirit of struggle and hard work, and the fight against misfortunes and so on.

The main purpose of the research is to deal with the background and knowledge of the selected topic, the profound meaning of Hayao Miyazaki's animation and the spread of Confucian culture in his animations which convey distinctive ethos and the advanced experience of success. The inherited traditional oriental cultural morality and the pursuit of universal values, such as people's care for the vulnerable, their cherishing of the family, their praise of the friendship, their encouragement for the spirit of struggle and hard work, and their fight against misfortunes will be expounded in the thesis. The main problem we would like to solve in the thesis is to what extent Hayao Miyazaki's animations play a role in spreading Confucianism to the world.

\section{The Spread of Confucianism in Hayao Miyazaki's Animations}

Hayao Miyazaki has always had a sharp eye for the awkward, unbalanced movement of physical objects in space, while his stories owe more to fables and fairy tales than to histories or headlines. Hayao Miyazaki's animation is closely related to the historic culture and the artistic tradition of the east. He was against the unjust war, and the formation of his anti-war ideology was connected with the influence of domestic political corruption, collapse of the Soviet Union, Gulf War and Civil War in Yugoslavia. He has been longing for the harmony of human and nature, appealing to environmental protection, condemning the alienation of human nature and initiating philanthropism and forgiveness. Hayao Miyazaki held the ecological view of counter-anthropocentrism, so he was honoured as an environmentalist hierarch. His depicting of a pessimistic optimism through one after another story of Messianic Salvation, has expressed his seeking of an ideal relationship between human and nature in a romantic way. Miyazaki's animations, both hand-painted ones and those aided by carefully used computer effects, have never been more beautiful, which pay attention to details and buildings of a wonderful imaginative world. This succeeds in emphasizing Miyazaki's recurrent theme of harmony with nature.

Confucianism is not generally considered a religion or practiced like a religion, nor did it inspire great schools of art. Rather, Confucianism developed as a set of ethical and political tools, a basket of norms that emphasized filial piety, respect for elders, social obligations, and rules of courtesy that promised humanistic, rational, and benevo- 
lent governance, harmonious family relationships, and clear-cut standards for governing the interaction among rulers, lords, vassals, and common folk, between old and young, father and son, husband and wife, etc. [2]. Over many centuries, it has developed into an overarching set of moral laws, and for centuries served as the basis of China's allimportant civil examinations, which stressed the value of Confucian learning and the importance of scholarly officials who would be led by virtuous examples.

Confucianism is a world heritage shared by many writers, and Hayao Miyazaki is no exception. It is significant to spread Confucianism to the world in the media so that the world will be a better place and a more harmonious place to live in for us, and for our children. And Hayao Miyazaki has inherited traditional oriental cultural morality, and embodied the pursuit of universal values, such as people's care for the vulnerable, their cherishing of the family, their praise of the friendship, their encouragement for the spirit of struggle and hard work, and their fight against misfortunes. These universal values such as benevolence, righteousness, wisdom, faithfulness, honesty, courage, loyalty and filial piety, which are described in Hayao Miyazaki's animations, play an important role in spreading Confucianism to the world. It is of practical significance for us to deal with how Hayao Miyazaki has spread Confucian culture in his animations, and this will shed new light on the spread of culture.

\subsection{Benevolence and Righteousness}

In Hayao Miyazaki's animations, benevolence refers to love, righteousness refers to justice.

Many of Miyazaki's films deal with the power of love. In Miyazaki's films, the power of love is powerful enough to lift curses set upon people. In "Spirited Away", Kamajii tells Haku that Chihiro saved him from Zeniba's curse with the power of her love for him. In "Howl's Moving Castle", Sophie's confidence in herself and her love for Howl breaks the curse laid upon her by the Wicked Witch of the Waste. In Miyazaki's screenplay of "Whisper of the Heart", Shizuku's love for Seiji makes her follow her passion of writing and complete the book while Seiji is away in Cremona, Italy. In "Ponyo", if Sousuke's love for Ponyo was true then the world would be saved.

Ponyo is a child's film based on the story of The Little Mermaid. Ponyo is a goldfish who wants to be human. She escapes her father's boat and befriends a 5-year-old boy named Sosuke. Ponyo struggles to maintain her magic as she also learns what it is like to be human. Ponyo's power ends up becoming unstable as the moon gets closer to the earth, which causes the ocean to rise. Ponyo is a child's film much like Miyazaki's other films which test the power of love. Ponyo's themes are environmentalism, love, and a child's spirit. Environmentalism is shown through the pollution in water. It has also shown how dangerous it is to the fish when Ponyo is swimming away from the danger of the propeller. As she does this, her head ends up getting stuck inside a bottle. Love is what makes Ponyo human and what makes for a happy ending. Ponyo is full of energy to the point that her father has a hard time to control her. The child spirit is shown in this film, which shows the imagination of a child through the art and the two children. 
The ocean is alive with so many colors and fish.

Spirited Away, perhaps Japanese animation master Hayao Miyazaki's greatest work of art [3], is the beautiful and engrossing tale of a young girl, Chihiro, who enters a magical world through an abandoned amusement park [3]. Of course, such a summary necessarily fails to do justice to the grand imagination displayed in the film. Princess Mononoke and Spirited Away revealed the theme with implication, interest and exaggeration that the hope of human beings only lay in love.

Hayao Miyazaki has a strong sense of social responsibility. He aims to change the society and thinks that only people who hold such a conception can make true animations. The characters in his animations who lead the military forces are almost blinded by their gains. They started a war, hurt the innocent and caused the death of many people, such as Cagliostro in The Castle of Cagliostro, Kushana and Pejite in Nausicaä of the Valley of the Wind, Muska in Castle in the Sky and Suliman in Howl's Moving Castle. Although these animations were adapted from masterworks of imaginary mystifying history in Japan, they were the artistic expressions of the sins of the World Wars by Hayao Miyazaki. They were drawn to criticize and warn warmongers and careerists.

\subsection{Wisdom}

In Hayao Miyazaki's animations, wisdom refers to consciousness. People should understand the importance of the truth that we must have harmonious relationships with nature. The counter-anthropocentrism is very popular in contemporary western world, which is abstract and idealized. The reasons of its appearance involve practical reasons and spiritual traditions. From the practical reasons, counter-anthropocentrism came into existence at the background of the global environmental crisis. It tried to restrict behaviors and strengthen the human ecological consciousness through establishing moral norms between human beings and nature, thus solving the ecological problems. Its philosophic rethinking has important intellectual significance that people should reexamine the objective relationship of human and nature for macroscopic and longterm consideration, and advocate to develop and make use of natural resources temperately, which also had far-reaching significance in warning people to respect and care for the environment and in raising public awareness of environmental protection.

In the past, people hesitated to kill. But society has changed. They are not hesitating any more. People become strong and arrogant with the development of technology in conquering and tapping the environment. The using of fire and iron played an important part in this process and this was the reason why Hayao Miyazaki was worried. In Nausicaä of the Valley of the Wind, Kushana killed out giant insects with the fire spitted from Colossus. In Princess Mononoke, Mononoke's weapon is a roer. Fire is the powerful power to conquer nature by human beings, so is iron. People in Tatara Ba cut down woods for smeltering iron, and consequently the forest gods have to fight for their living place. The struggle was irreconcilable. With the help of gunpowder and iron, a state of power balance between human beings and animals was changed [4]. People didn't revere nature anymore and thought they were the masters of nature after 
they gained advantage and success in the war of fighting for living place with other living things by using gunpowder and iron. The mendicant monk in Princess Mononoke said that the nature of human beings is attempting to hold universe in their hands [4]. Greedy people are centered on their own benefits, trying in vain to deprive other living things of their life and living space. While talking about the short film On Your Mark he felt angry and said, "From the history of damaging this earth, the appearance of human beings was like the rapidly spreading disease. Even if you save an angel, you could do nothing about saving the world" [5]. Many fictional works expressed the same viewpoint with Hayao Miyazaki. They were not only describing what science and technology brought us but also revealing the correlations between technology, society and nature and human existence [4].

The relationship of human beings with animals was at daggers, drawn over the damage brought up by human beings, which threatened the animals' living, environment and led to a series of conflicts and battles. In Hayao Miyazaki's view, war is inevitable because living space is limited. In Nausica's dream, her father let her hand over the larva and said that human beings and larva cannot coexist. Kushana also said, we insecticide to regain the ground which belonged to human beings, so she resurrected the monster and used it to defeat the larva. People always thought they are stronger than animals. For example, the royal secret agent monk in Princess Mononoke persisted that Celestial Empire would subdue the Kylin. That made Kylins angry. The monk is still unwilling to hand over the head of dead Kylin even though that behavior will spell disaster [3]. Anthropocentrism always spells a disaster. In Hayao Miyazaki's opinion, it's all the fault of human beings, and the hatred of the animals was passive and helpless.

It was full of pollution and downfall instead of green vegetation in the place where human technology existed in Hayao Miyazaki's animations. In Nausicaä of the Valley of the Wind, the army brought death and separation to the city where they arrived. People had to wear gas masks to prevent spores. The Colossus which slept underground resurrected and caused trouble. In Princess Mononoke, the deep dismal voice-over said, a long long time ago, this country was covered by thick forests, gods lived there from ancient times. Then we saw the trees fallen down one by one, and the green and luxuriant earth became gray. Smoke was billowing from Mononoke's iron town, and it was like a scar in the forest from extreme long shot. And the firearm maker designed to be the leper who masked all year around showed Hayao Miyazaki's opinion that the firearm maker who killed forest gods was sick [4]. Then the forest gods changed to be monsters that destroyed vegetation. Ashitaka was cursed for killing the monster that hurt his own people. He was the victim of human hostility for animals.

There is no calmness and peace in the industrial society in Castle in the Sky. Hayao Miyazaki thought that the power of nature was stronger than that of technology, and that people are going to die if they attempt to challenge it. As the old woman in Nausicaä of the Valley of the Wind mentioned, the anger of the giant insects is the same as that of the world. In Castle in the Sky, the little girl Hida seeks her lost native land, at the end of this long journey, with the castle in the sky in the company of little boy Bass, 
and finally realizes that people cannot leave the land no matter how the technology progresses and how the society develops. The destruction of Laputta warns people that what we are facing is an unknown future for this mechanized iron century. The monk in Princess Mononoke said that it is a sin for people to possess universe. Greed is what Hayao Miyazaki talked about human nature. He emphasized the importance of a harmonious relationship between human and nature.

\subsection{Faithfulness}

In Hayao Miyazaki's animations, faith refers to the belief in the power of dreams to streamline work, life, and love. In the past, Miyazaki has celebrated the free play of the imagination as a buffer against industrialization (Spirited Away), environmental devastation (Princess Mononoke), and war (Howl's Moving Castle). Like those films, The Wind Rises is a manifestation of faith in the power of dreams to streamline work, life, and love into a single, frictionless whole-an ideal represented here by Jiro's design for an impossibly light and fast fighter plane. The irony is that, in the war-torn world of The Wind Rises, dreaming about the abstract light and graceful plane is dangerously close to dreaming up new and better weapons to kill.

As the film goes on, its story shifts away from Jiro's professional life to his marriage with Kayo, a beautiful young painter with a soft disposition and a weak state of health. Miyazaki fills out their storybook romance with an abundance of finely described details: she, curled up inside a sanatorium sleeping bag, scribbling a love letter as lonely flakes of snow drift through the opening; he glances nervously across a restaurant in her direction through the speared leafy greens of a fellow diner; the couple stand outside, with their clothes billowing tenderly in the breeze.

In its well-organized, pious purity, their love story might seem closer to Camelot than to 20th-century Japan. But when Miyazaki's couple reenact a classic romantic setup-the lady leaned on a balcony, her suitor wooing her from below-there's an ominous picture: they're tossing a paper airplane back and forth. What Miyazaki is getting at is that sustaining this idealized kind of soul-to-soul contact requires an extreme act of faith in your own imaginative powers-a kind of withdrawal from reality. And that this liftoff from reality, born out of a drive for total imaginative freedom, can also result in the kind of moral self-immunity that leads conscientious young people happily into war.

And that's where the film ends: inside a dream that conflates the loss of a loved one with defeat in a war, while at the same time suggesting that, in dreams, nothing is ever really lost. In other words, Miyazaki stays devoutly committed to the idea that, given enough faith and force of will, an individual can recreate the world without giving up an inch of his or her inner vision-for better or worse. The film returns, mantra-like, to a line from Paul Valéry: "Le vent se lève/Il faut tenter de vivre" ("The wind rises ... One must try to live"), which is both fitting and disagreeable: fitting, because it reflects the film's image of the lone dreamer struggling to maintain his integrity in an unstable world; disagreeable, because it mirrors the necessity for compromise that the film refuses to make. 


\subsection{Courage}

Chihiro's "large heartedness" wins the day, as she meets with unforgettable characters such as Haku, No Face, and a number of spirits selected from both Japanese tradition and the unique imagination of Miyazaki. While Spirited Away's real stakes and sense of danger, as well as the dearth of clear-cut good and evil characters, might disqualify its appropriateness for all ages in some quarters, but it does give the film a greater thematic weight and helps it to earn its place as one of the great films of the early twenty-first century [3]. Chinese and the Westerners have much to learn from the Japanese in realizing that animation is not just for children. Spirited Away offers guidance for living in a recognizable postmodern world, where the only sure thing is kindness [3].

My Neighbor Totoro is an exciting sweet film, filled with Miyazaki's love not just for animation, but also for the art of filmmaking. And that is exactly what the film is, a true work of artistry. The film is an innocent and delightful creation, filled with a kindness that only the imagination of a child could ever project [6]. To see My Neighbor Totoro is to be sent to a world of no evil, little sadness, and beautiful images of exaggerated fantasies. The film's world is mostly dubbed through the eyes of two sisters. Satsuki, as the elder of them, must take care of her younger sister, Mei. Mei is a hotheaded and often extremely excited young girl. She is a feeling of true enrichment and passion for imagination and creativity, felt strongly throughout the film [6]. If Mei represents the feeling of child joy and freedom of creative expression, Satsuki is often shown as a transformative loss of innocence reflected in a result of growing older and gaining larger responsibility. This is felt strongly in many sequences when Mei becomes lost or upset. In absence of their father at times, Satsuki must undertake a sense of authority and adulthood, often having to solve any problems that Mei may face in turn, trying to deal with both of their anxieties, which arise from one main source in the film, the health and welfare of Satsuki and Mei's mother, who is ill in hospital. The girls move to a new house with their interesting and kind-hearted father, who cares for the girls while working as a college professor. He is a noble man, and tries his best, but struggles to handle his work with caring for the girls, often resulting in long periods of his absence. Because of this, Satsuki and Mei are at times left to freely explore the world of the forest that lies beside their new home, and they do so in an extremely courageous manner. Totoro comes up to the girls whenever they are in need of a smile. Whether he is the man in the moon or not, he truly helps them overcome their dilemma [6].

Totoro to them seems to fill an emotional gap, left wide open and vulnerable due to their mother being very sick [6]. Totoro and his friend do all they can to support the girls through this, providing them with wondrous adventures and magical fantasy. At one point he even hands out seeds to the girls, helping them to spontaneously grow these small seeds into a gigantic tree, which has mysteriously disappeared the very next day.

\subsection{Loyalty and Filial Piety}

In Hayao Miyazaki's animation, devotion refers to being loyal to the motherland and 
filial piety refers to treating one's parents with love and care.

Spirited Away was a different film for many reasons. The main character and hero of the story is Chihiro, a ten year old girl. She saves her parents by "saving the day" against unnatural enemies without violence, but instead with compassion and devotion. Although not physically strong, Chihiro is undoubtedly a hero, leading to the thought of a change in the direction of mankind. Chihiro ultimately represents Miyazaki's alternative solution to the cultural, environmental and societal issues the world faces, and helps to recognize that change which needs to be made in order for the future of our race to survive [3].

The main character Chilhiro in Spirited Away was entirely different from the female roles in Hayao Miyazaki's past work [3]. She was not brave and lovely in her first appearance. For the creation motive and background, Hayao Miyazaki explained that there were many girls like Chilhiro in Japan and he was not just doing a vivid portray of her. Those girls ignored all efforts that their parents have done for them just like a memorable scene in this movie when Chilhiro responded to her parents after they called her for the second time. And he repeated this kind of scene for the third time to remind the girls to respect and honor their parents.

Marco Pagot, a name which came from a friend of Hayao Mayazaki who was an Italian cartoonist, was the best pilot of the Italian Air Force in World War I. He has intended to marry with Gina who was living on the island, the territory of Austria, but then he called off the engagement after World War I broke up and served himself in the war as an officer. Finally his loyalty forced him to stand on the side of his motherland.

\section{Conclusion}

The innovation we make in the study is that the thesis mainly focuses on the spread of the culture and thought of Confucius which appear in Hayao Miyazaki's animations. We have not found any previous research on the discussion of Hayao Miyazaki's animations from the perspective of the spread of Confucianism. The paper concludes that what impacts Confucian cultural concepts have on Hayao Miyazaki's animations is to fuse with life such moral values as benevolence, righteousness, wisdom, faith, courage, loyalty and filial piety. The limitation of the study is that more discussions on the spread of the culture and thought of Confucius which appear in Hayao Miyazaki's animations should have been made. Due to the lack of time and energy, this thesis is only a first try to the study of this topic. Hope more research will be made on and more attention will be paid to this topic. And future research is needed on the study of the spread of Confucianism in Hayao Miyazaki's animations.

\section{References}

[1] Forbes, D. (2005) Analysis Cartoons: Toontown's Greatest Characters. The Independent.

[2] Wikipedia. Confucius. 10 May 2014. http://en.wikipedia.org/wiki/Confucius

[3] Gerow, A. (1997) A Spirited Battle for Nature. Daily Yomiuri, 9.

[4] Klady, L. (1998) Princess Mononoke. Variety. Reed Business Information. Retrieved Sep- 
tember 14, 2012.

[5] Miyazaki (1997) Princess Mononoke. Metacritic, CBS Interactive.

[6] Pilling, D. (2007) Defining Moment: My Neighbour Totoro, 1988, Directed by Hayao Miyazaki. Financial Times, 15 September 2007.

Submit or recommend next manuscript to OALib Journal and we will provide best service for you:

- Publication frequency: Monthly

- 9 subject areas of science, technology and medicine

- Fair and rigorous peer-review system

- Fast publication process

- Article promotion in various social networking sites (LinkedIn, Facebook, Twitter, etc.)

- Maximum dissemination of your research work

Submit Your Paper Online: Click Here to Submit

Or Contact service@oalib.com 